\begin{abstract}
HETEROCYCLES, Vol. 95, No. 1, 2017, pp. -. (C) 2017 The Japan Institute of Heterocyclic Chemistry Received, 28th April, 2016, Accepted, 27th May, 2016, Published online, DOI: $10.3987 / C O M-16-S(S) 2$
\end{abstract}

\title{
SYNTHETIC STUDY TOWARDS CONSTRUCTION OF POTENTIAL SCAFFOLD OF ANTITUMOR AGENTS ANDRASTINS
}

\section{Shuqiang Yin, ${ }^{\mathrm{a}}$ Kenji Sugimoto, ${ }^{\mathrm{a}}$ Hideo Nemoto, ${ }^{\mathrm{b}}$ and Yuji Matsuya ${ }^{\mathrm{a}, *}$}

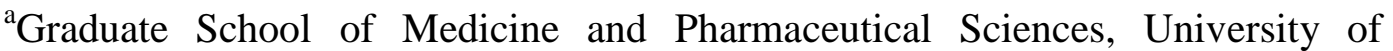

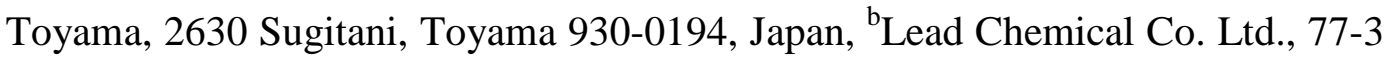
Himata, Toyama 930-0912, Japan. E-mail: matsuya@pha.u-toyama.ac.jp

\begin{abstract}
For a construction of potential scaffold of antitumor agents andrastins, intramolecular Diels-Alder reaction of the triene composed of trans-fused AB ring with tethered $\mathrm{D}$ ring was examined. The reaction in refluxing toluene afforded a desired cis-fused hydrindane skeleton, the relative stereochemistries of which were unambiguously determined by X-ray crystallographic analysis.
\end{abstract}

\section{INTRODUCTION}

Andrastins A-D were isolated from the cultured broth of Penicillium sp. FO-3929 and were reported as potent inhibitors against protein farnesyltransferase (PFTase) in a dose-dependent manner. ${ }^{1}$ Since PFTase catalyzes an introduction of farnesyl group on the ras protein precursor produced by one of the representative cancer genes (ras gene family), PFTase inhibitor andrastins are believed to be an attractive lead for novel anti-cancer drug.

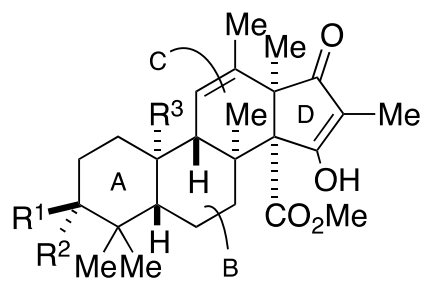

$$
\begin{aligned}
& \text { andrastin } A(1): R^{1}=O A c, R^{2}=H, R^{3}=C H O \\
& \text { andrastin } B(2): R^{1}=O A c, R^{2}=H, R^{3}=\mathrm{CH}_{2} O H \\
& \text { andrastin } C(3): R^{1}=O A c, R^{2}=H, R^{3}=M e \\
& \text { andrastin } D(4): R^{1}=R^{2}=O, R^{3}=C H O
\end{aligned}
$$

Figure 1. Structures of andrastins

Not only for its fascinating biological activity, but for its characteristic structures involving trans-anti-trans fused $\mathrm{ABC}$ rings, cis-fused $\mathrm{CD}$ ring juncture, three contiguous quaternary stereogenic centers, and $\beta$-diketone functionality on D ring, andrastins have been an attractive synthetic target. Among the unique structural units, efficient construction of angularly substituted cis-hydrindane skeleton has been a problem to be solved and several synthetic efforts have been reported as follows. ${ }^{2}$ 
Intramolecular Hosomi-Sakurai reaction was effectively utilized for a diastereoselective cis-hydrindane synthesis. ${ }^{2 a, b}$ Intramolecular cyclopropanation of olefins with keto carbenoid species afforded a tricyclic ketone incorporating cis-fused-6,5-bicyclic system and successive reductive cleavage of cyclopropane ring established substituted cis-hydrindanes. ${ }^{2 \mathrm{c}-\mathrm{e}}$ Highly hindered cis-hydrindane was elaborated by $\alpha$-carbonyl radical cyclization reaction. ${ }^{2 f}$ Cycloisomerizations are one of the strategies for cis-hydrindanes and the several reactions using stoichiometric Brønsted acid or catalytic $\pi$-philic acid have been reported. ${ }^{2 g-1}$ For a construction of cis-fused ring systems, cycloaddition would be considered as a powerful methodology and inter- or intramolecular Diels-Alder reactions were actually employed. ${ }^{2 \mathrm{~m}-0}$ Recently Toyota and co-workers succeeded in a construction of the cis-hydrindane skeleton with ene reaction from the highly advanced precursor. $^{2 p}$ Despite of these developments, total syntheses of andrastins have never been achieved since their isolation and they are still challenging targets.

Our group has also been interested in the total synthesis of andrastins and could have originally achieved a stereoselective synthesis of tricyclic BCD core 6 based on intramolecular Diels-Alder approach for the construction of cis-fused CD ring as depicted in Scheme $1 .^{3}$

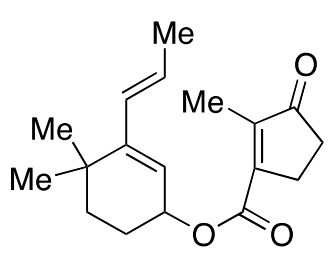

5

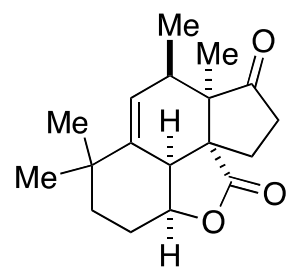

$6($ endo): $53 \%$

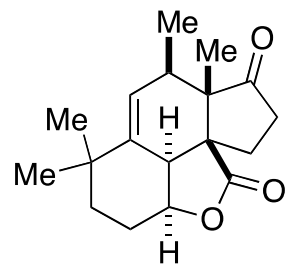

7 (exo): $20 \%$

Scheme 1. Intramolecular Diels-Alder reaction strategy

Thus, the potential scaffold of andrastins, pentacyclic compound $\mathbf{8}$ could be established by the intramoleculer endo-selective Diels-Alder reaction of $\mathbf{9}$, which was more advanced substrate than that in our previous report, enabling an installation of the continuance quaternary stereogenic centers on CD ring juncture in highly stereoselective manner by the aid of ester linker (Scheme 2). The key Diels-Alder precursor $\mathbf{9}$ could be furnished by an esterification of dienyl alcohol 11 with cyclopentene carboxylic acid 10. ${ }^{3}$ Chemoselective introduction of propenyl group followed by a diastereoselective reduction of the remained keto group on 12 could lead into 11. Diketone 12 would be constructed from 13 through an allylic oxidation and a reduction of the resultant enone. The decalin framework $\mathbf{1 3}$ can be derived from Wieland-Miescher ketone (14) via several functionalizations. Since the introduction of quaternary methyl group on BC ring juncture would be possible by utilizing oxygen functionality on B ring, this synthetic strategy would enable the syntheses of andrastins and norandrastins via a potential scaffold as a pivotal synthetic intermediate. 


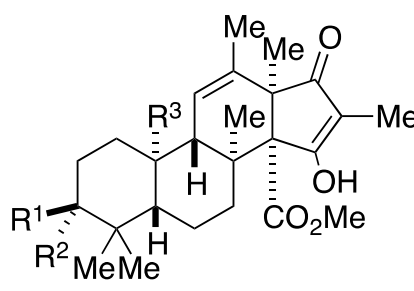

andrastins

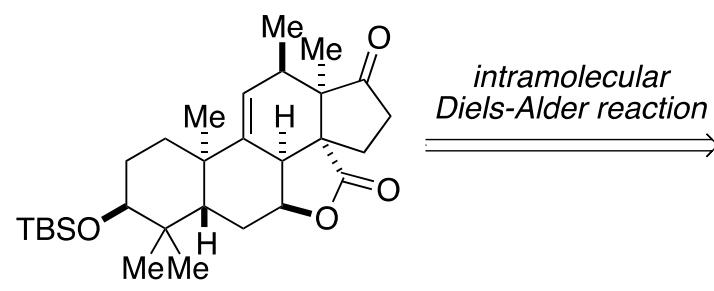

potential scaffold (8)

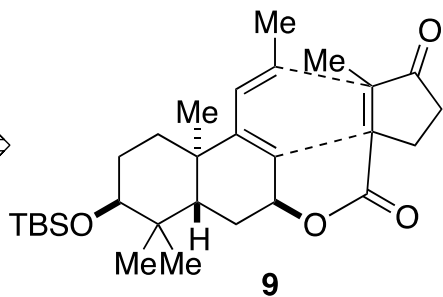

$\|$<smiles>CC12CCC(=O)C=C1CCCC2=O</smiles>

Wieland-Miescher ketone

(14)<smiles>CC(C)(C)O[C@H]1CC[C@]2(C)C(=CCCC23CCOC3)C1(C)C</smiles>

13

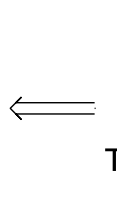

TBSO

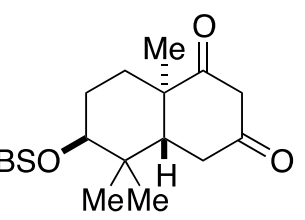

12

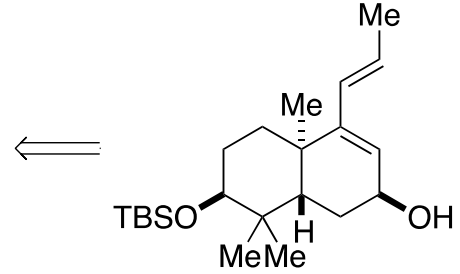

11

Scheme 2. Retrosynthetic analysis on andrastin C

\section{RESULT AND DISCUSSION}

Starting with the optically pure Wieland-Miescher ketone $(\mathbf{1 4})^{4 \mathrm{~b}}\left([\alpha]_{\mathrm{D}}{ }^{25}-99.1\right.$ (c 2.10, benzene), lit. $[\alpha]_{\mathrm{D}}^{25}-98.96$ (c 1.039, benzene $)^{4 \mathrm{~b}}$ ), acetalization followed by dimethylation concomitant with olefin isomerization afforded the ketone 16 with high yields (Scheme 3). L-Selectride was found to be effective for a diastereoselective reduction of the carbonyl group from the convex face and the $\beta$-hydroxy compound $\mathbf{1 7}$ was obtained as a sole isomer. The resultant hydroxy group was protected as TBS ether and allylic oxidation of $\mathbf{1 3}$ was examined. While the oxidation with $\mathrm{SeO}_{2}$ in $\mathrm{CH}_{2} \mathrm{Cl}_{2}$ at room temperature nor in refluxing $\mathrm{ClCH}_{2} \mathrm{CH}_{2} \mathrm{Cl}$ gave the desired enone 18, $\mathrm{CrO}_{3}-3,5$-dimethylpyrazole ${ }^{5}$ worked well to give 18 in good yield.

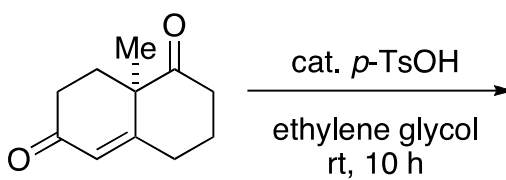

14<smiles>CC12CCCC3=CC(=O)CCC31OCCO2</smiles>

15

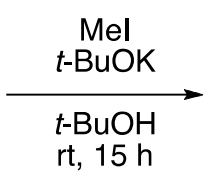

$79 \%$<smiles>CC1(C)C(=O)CCC2C1=CCCC21OCCO1</smiles>

16

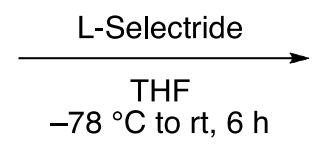

$85 \%$<smiles>CC1(C)C2=CCCC3(OCCO3)C2CCC1O</smiles>

17<smiles>CC1(C)C2=CCCC3(OCCO3)C2CCC1OS(C)(=O)=O</smiles>

13

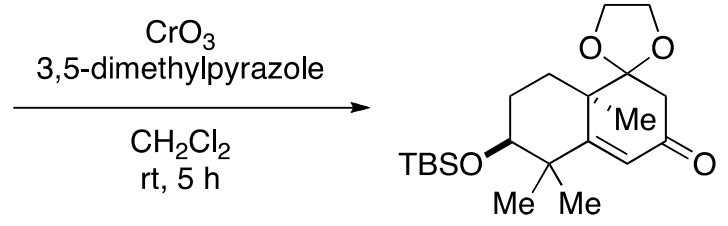

$82 \%$

Scheme 3. Preparation of enone $\mathbf{1 8}$ 
For the intramolecular Diels-Alder reaction, we prepared the diene part as shown in Scheme 4. With the enone 18, diastereoselective reduction of the olefin was firstly examined. The sterically hindered olefin, both face of which would be blocked by two axially oriented methyl groups, was never affected by a hydrogenation reaction with Pd/C. On the other hand, the reduction with dissolving metals was effective and resulted in fair to good yields. While the diastereomixture of 19 and $\mathbf{1 9}^{\prime}\left(\mathbf{1 9 : 1 9} \mathbf{\prime}^{\prime}=1: 1\right)$ was given in moderate yield by a reaction with $\mathrm{Li}$ in liquid ammonia, $\mathrm{Na}$ was found to be reliable to furnish thermodynamically more stable 19 selectively in $60 \%$ yield. After a manipulation of the protective group on the carbonyl groups, (E)-propenyl group was successfully introduced on C9 (andrastin numbering) and subsequent hydrolysis of the enol ether to afford dienone 21. For an installation of dienophile moiety, the keto group was reduced with DIBAL. The reaction gave a mixture of diastereomers and NOE correlations between $\mathrm{H}^{\mathrm{a}}$ and protons $\mathrm{H}^{\mathrm{b}}, \mathrm{H}^{\mathrm{c}}$, and $\mathrm{H}^{\mathrm{d}}$ in a major product revealed that the major one was alcohol 11' (Figure 2), which would be caused by a reduction from a sterically less hindered $\beta$-face of 21 avoiding an axial oriented angular methyl group. ${ }^{7}$

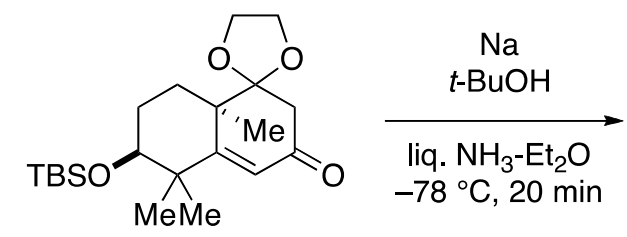

18

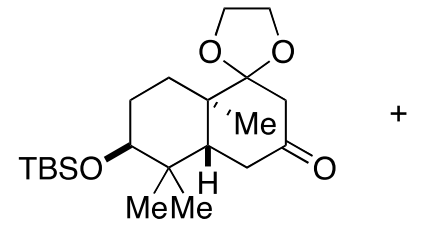

19: $60 \%$

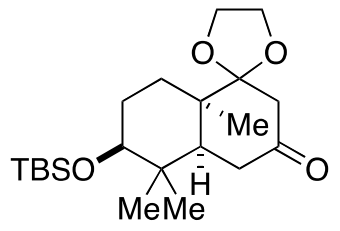

19': $13 \%$

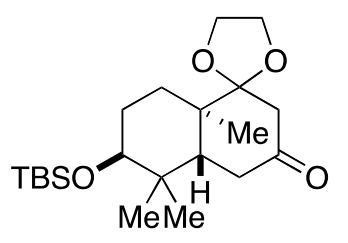

19

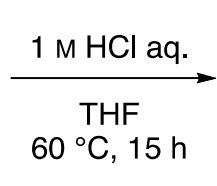

$97 \%$

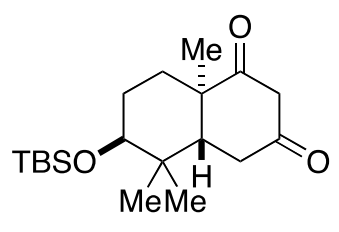

12

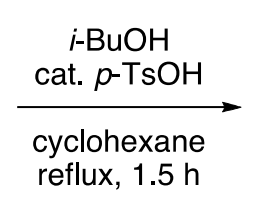

$83 \%$

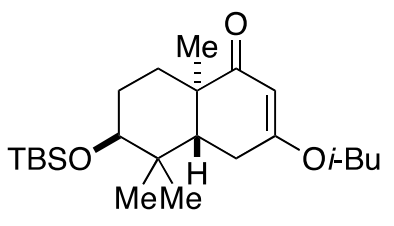

20

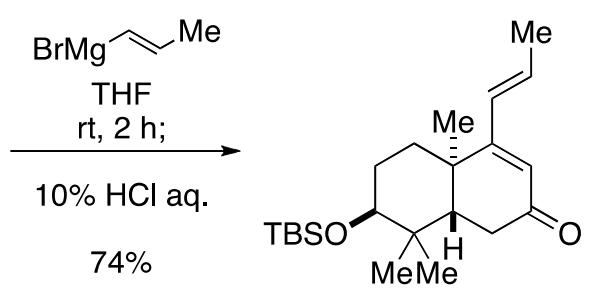

21

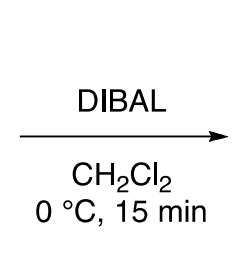

TBS

11: $9 \%$

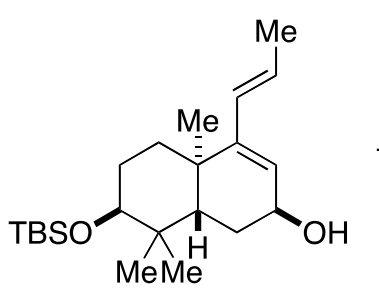

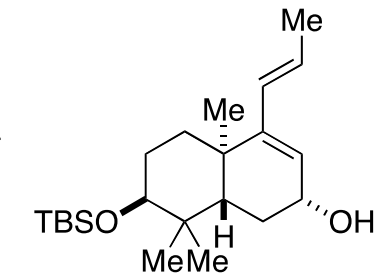

11': $79 \%$

Scheme 4. Construction of diene part 


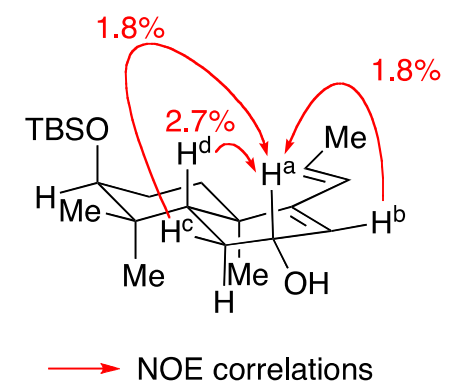

Figure 2. NOE correlations in alcohol 11'

With the diene 11' in hand, a dienophile cyclopentenone unit was introduced by Mitsunobu reaction ${ }^{6}$ to afford the Diels-Alder reaction precursor 9 (Scheme 5). Because of its instability, the precursor 9 was conducted immediately to the Diels-Alder reaction after a quick and simplified purification through a pad of silica gel. Finally, a heating of $\mathbf{9}$ in refluxing toluene for $15 \mathrm{~h}$ furnished the desired Diels-Alder adduct $\mathbf{8}$ in 10\% yield with a concomitant generation of triene 22 via a conjugative elimination reaction of the ester group. The relative stereochemistries on $\mathbf{8}$ were unambiguously determined by its X-ray crystallographic analysis as an endo-adduct (Figure 3). The reactions conducted under lower temperature in the presence of Lewis acids $\left(\mathrm{Me}_{2} \mathrm{AlCl}\right.$ or $\left.\mathrm{Yb}(\mathrm{OTf})_{3}\right)$ disappointingly promoted the analogous conjugative elimination reaction.

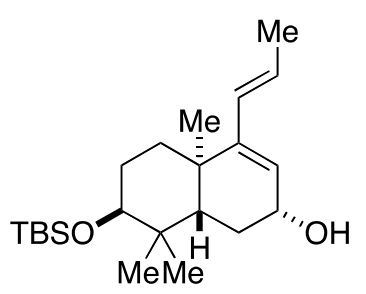

$11^{\prime}$
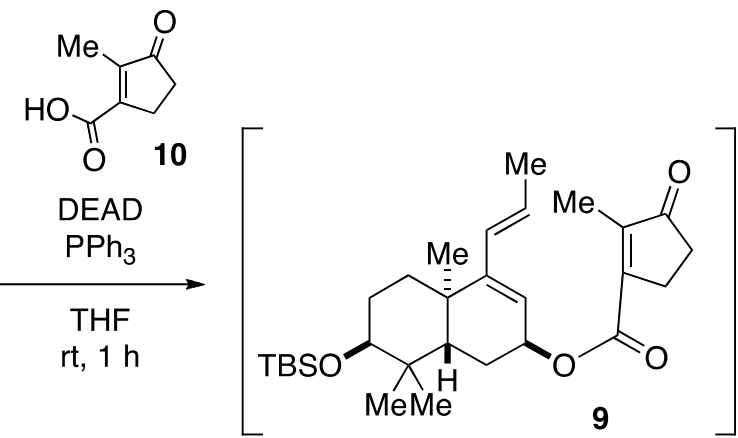

toluene reflux, $15 \mathrm{~h}$

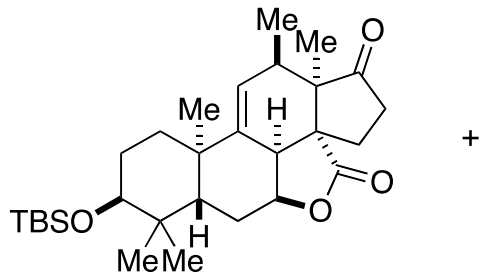

8: $10 \%$

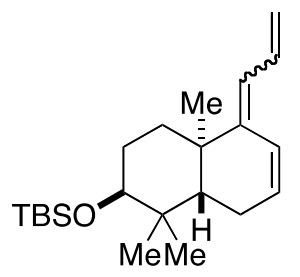

22: $50 \%$

Scheme 5. Diels-Alder reaction for a construction of potential scaffold of andrastins 


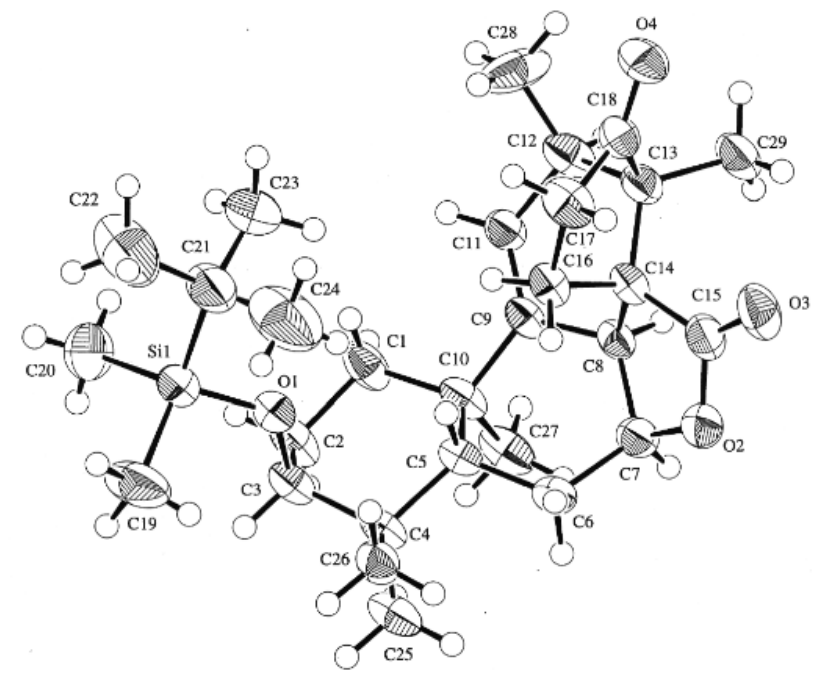

Figure 3. ORTEP structure of 8

The tendency toward such conjugated elimination of the ester group could be rationalized by the conformational restriction of the substrate. The ester group would be enforced in pseudoaxial position to overlap with the bonding $\pi$-orbital of adjacent diene moiety, which is undesirable but ideal for the elimination process, by the rigid trans-decalin framework (Figure 4). In our previous study (Scheme 1), ${ }^{3}$ the Diels-Alder precursor 5 would be free from such fixation of conformation.

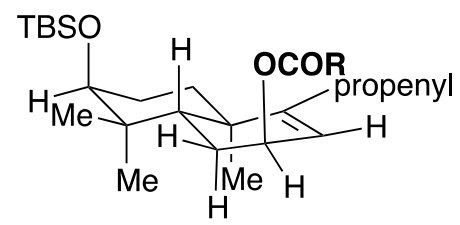

Figure 4. Supposed conformation of Diels-Alder reaction precursor 9

In summary, we applied our Diels-Alder approach to construct a cis-hydrindane unit from trans-fused AB ring tethered with D ring precursor and, even though the chemical yield stayed in low, the strategy was proved to afford the desired potential scaffold of andrastins by the aid of the intramolecular lactone formation. Further synthetic studies for potential scaffold of andrastins using Diels-Alder strategy is ongoing in our laboratory.

\section{EXPERIMENTAL}

All nonaqueous reactions were carried out under an Ar atmosphere. Reagents were purchased from commercial suppliers and used as received. Anhydrous solvents were prepared by distillation over $\mathrm{CaH}_{2}$, or purchased from commercial suppliers. ${ }^{1} \mathrm{H}$ and ${ }^{13} \mathrm{C}$ NMR spectra were recorded on a JEOL ECX 400 instrument, Chemical shifts for ${ }^{1} \mathrm{H}$ and ${ }^{13} \mathrm{C}$ NMR spectra are reported in ppm $(\delta)$ relative to the residual 
${ }^{1} \mathrm{H}$ and ${ }^{13} \mathrm{C}$ signals of the solvent $\left(\mathrm{CHCl}_{3}: \delta 7.26 \mathrm{ppm}, \mathrm{CDCl}_{3}: \delta 77.0 \mathrm{ppm}\right)$ and the multiplicities are presented as follows: $\mathrm{s}=$ singlet, $\mathrm{d}=$ doublet, $\mathrm{t}=$ triplet, $\mathrm{q}=$ quartet, and $\mathrm{m}=$ multiplet. Mass spectra were measured on a JEOL JMS-GCmate II or a JEOL JMS-AX 505 HAD mass spectrometer, and the ionization method was electron impact (EI, $70 \mathrm{eV}$ ). IR spectra were recorded on a JASCO FT/IR-460Plus spectrometer. Column chromatography was carried out by employing Cica Silica Gel 60N (spherical, neutral, 40-50 $\mu \mathrm{m})$.

(8aR)-3,4,8,8a-Tetrahydro-8a-methyl-1,6(2H,7H)-naphthalenedione 1-ethylene ketal (15). The Wieland-Miescher ketone $(\mathbf{1 4})^{4}(2.6 \mathrm{~g}, 14.6 \mathrm{mmol})$ was dissolved in ethylene glycol $(70 \mathrm{~mL})$, then p-TsOH (278 mg, $1.46 \mathrm{mmol}$ ) was added, the resulting solution was stirred at room temperature for $10 \mathrm{~h}$, after which it was poured carefully into a mixture of ice and saturated aqueous $\mathrm{NaHCO}_{3}$. The solution was then extracted with EtOAc $(50 \mathrm{~mL}$ x 4). The combined organic extracts were washed with water and brine, dried over $\mathrm{Na}_{2} \mathrm{SO}_{4}$, filtered, and evaporated under reduced pressure. The residue was purified by flash column chromatography on silica gel (hexane/EtOAc $=4: 1)$ to give $15(2.68 \mathrm{~g}, 83 \%)$ as a white solid.

Mp 51-52 ${ }^{\circ} \mathrm{C} ;{ }^{1} \mathrm{H}$ NMR (400 MHz, $\mathrm{CDCl}_{3}$ ) $\delta 5.75$ (1H, s), 3.92-3.87 (4H, m), 2.36-2.20 (5H, m), 1.881.60 (5H, m), 1.30 (3H, s); ${ }^{13} \mathrm{C}$ NMR (100 MHz, $\left.\mathrm{CDCl}_{3}\right) \delta 199.1,167.6,125.5,112.3,65.3,65.0,44.9$, 33.8, 31.3, 29.9, 26.7, 21.6, 20.4; IR (KBr) 2948, 1670, $1619 \mathrm{~cm}^{-1}$; HRMS (EI) calcd for $\mathrm{C}_{13} \mathrm{H}_{18} \mathrm{O}_{3}\left(\mathrm{M}^{+}\right)$ 222.1256, found 222.1289; $[\alpha]_{\mathrm{D}}{ }^{20}-102.6$ (c 1.06, $\left.\mathrm{CHCl}_{3}\right)$.

$(8 \mathrm{a})$-3,7,8,8a-Tetrahydro-5,5,8a-trimethyl-1,6(2H,5H)-naphthalenedione 1-ethylene ketal (16). In an atmosphere of argon a solution of 15 (2.09 g, $9.4 \mathrm{mmol})$ dissolved in absolute t-butanol (4.2 mL) was dropped in $5 \mathrm{~min}$ at $10{ }^{\circ} \mathrm{C}$ into a solution of potassium $t$-butoxide (5.91 g, $52.7 \mathrm{mmol}$ ) in $t$-butanol (63 $\mathrm{mL}$ ). After having vigorously stirred for $10 \mathrm{~min}$ at this temperature, methyl iodide (7.61 mL, $122.2 \mathrm{mmol}$ ) was added in 10 min while cooling with ice water. Then the reaction mixture was allowed to warm to room temperature for another $15 \mathrm{~h}$, which was concentrated in vacuo. The residue was then diluted with water and extracted with $\mathrm{Et}_{2} \mathrm{O}(30 \mathrm{~mL}$ x 4). The combined organic extracts were washed with water and brine, dried over $\mathrm{Na}_{2} \mathrm{SO}_{4}$, filtered, and evaporated under reduced pressure. The residue was purified by flash column chromatography on silica gel (hexane/EtOAc $=3: 1)$ to give $\mathbf{1 6}(1.88 \mathrm{~g}, 79 \%)$ as a colorless oil.

${ }^{1} \mathrm{H}$ NMR (400 MHz, $\left.\mathrm{CDCl}_{3}\right) \delta 5.50(1 \mathrm{H}, \mathrm{dd}, J=3.6,3.6 \mathrm{~Hz}), 3.98-3.84(4 \mathrm{H}, \mathrm{m}), 2.54-2.35(2 \mathrm{H}, \mathrm{m})$, 2.22-2.14 (3H, m), 1.86-1.78 (1H, m), 1.66-1.57 (2H, m), 1.18 (6H, s), $1.04(3 \mathrm{H}, \mathrm{s}) ;{ }^{13} \mathrm{C}$ NMR (100 $\left.\mathrm{MHz}, \mathrm{CDCl}_{3}\right) \delta 215.8,147.3,119.5,111.9,65.0,64.7,48.8,42.1$, 34.0, 28.9, 27.0, 25.9, 24.6, 23.8, 23.4; IR (neat) 2972, 1709, 1143, $1038 \mathrm{~cm}^{-1}$; HRMS (EI) calcd for $\mathrm{C}_{15} \mathrm{H}_{22} \mathrm{O}_{3}\left(\mathrm{M}^{+}\right)$250.1569, found 250.1544; $[\alpha]_{\mathrm{D}}^{20}+11.7\left(\right.$ ( $\left.1.1, \mathrm{CHCl}_{3}\right)$. 
$(6 S, 8 \mathrm{a} R)-3,5,6,7,8,8 \mathrm{a}-H e x a h y d r o-6-h y d r o x y-5,5,8 \mathrm{a}-$ trimethyl-1(2H)-naphthalenone 1-ethylene ketal (17). To a solution of 16 (11.0 g, $43.9 \mathrm{mmol})$ in THF at $-78{ }^{\circ} \mathrm{C}, 1.0 \mathrm{M} \mathrm{L}-$ Selectride $(100 \mathrm{~mL}, 100 \mathrm{mmol})$ was dropwise added and maintained at that temperature for $6 \mathrm{~h}$. After the reaction had completed by TLC detection, it was quenched by $3.0 \mathrm{M}$ aqueous $\mathrm{NaOH}$ solution (200 mL) and $30 \% \mathrm{H}_{2} \mathrm{O}_{2}$ (200 mL), which was allowed to stir for $1 \mathrm{~h}$ at room temperature. The reaction solution was then extracted with $\mathrm{CH}_{2} \mathrm{Cl}_{2}$ (100 mL x 4). The combined organic extracts were washed with brine, dried over $\mathrm{Na}_{2} \mathrm{SO}_{4}$, filtered, and evaporated under reduced pressure. The residue was purified by flash column chromatography on silica gel (hexane/EtOAc $=3: 1)$ to give $17(9.43 \mathrm{~g}, 85 \%)$ as a white solid.

Mp 60-62 ${ }^{\circ} \mathrm{C} ;{ }^{1} \mathrm{H}$ NMR (400 MHz, $\mathrm{CDCl}_{3}$ ) $\delta 5.50$ (1H, s), 3.95-3.86 (4H, m), 3.42 (1H, s), 2.31-2.21 (2H, m), 2.13-1.98 (3H, m), 1.92-1.84 (1H, m), 1.67-1.57 (3H, m), 1.30 (3H, s), 1.24-1.20 (1H, m), 1.14 (3H, s), 1.12 (3H, s); ${ }^{13} \mathrm{C}$ NMR (100 MHz, $\left.\mathrm{CDCl}_{3}\right) \delta$ 145.4, 121.4, 112.9, 76.4, 65.3, 64.8, 42.2, 40.7, 30.0, 27.8, 26.7, 25.9, 24.3, 24.2, 22.3; IR (KBr) 3533, 2992, 1472, $1035 \mathrm{~cm}^{-1}$; HRMS (EI) calcd for $\mathrm{C}_{15} \mathrm{H}_{24} \mathrm{O}_{3}\left(\mathrm{M}^{+}\right)$252.1725, found 252.1706; $[\alpha]_{\mathrm{D}}{ }^{20}+75.2$ (c 1.23, $\left.\mathrm{CHCl}_{3}\right)$.

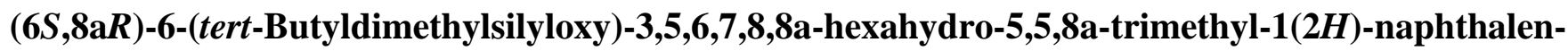
one 1-ethylene ketal (13). To a stirred solution of $17(1.1 \mathrm{~g}, 4.36 \mathrm{mmol})$ in DMF (40 mL) were added TBSCl (3.28 g, $21.8 \mathrm{mmol})$ and imidazole (1.48 g, $21.8 \mathrm{mmol})$ at room temperature. After stirring for 20 $\mathrm{h}$ at the same temperature, the reaction mixture was diluted with water and extracted with $\mathrm{Et}_{2} \mathrm{O}$ (50 mL x 3). The combined organic extracts were washed with water and brine, dried over $\mathrm{Na}_{2} \mathrm{SO}_{4}$, filtered, and evaporated under reduced pressure. The residue was purified by flash column chromatography on silica gel (hexane/EtOAc $=20: 1)$ to give $13(1.4 \mathrm{~g}, 88 \%)$ as a colorless oil.

${ }^{1} \mathrm{H}$ NMR (400 MHz, $\left.\mathrm{CDCl}_{3}\right) \delta 5.36(1 \mathrm{H}, \mathrm{dd}, J=3.6,3.6 \mathrm{~Hz}), 3.95-3.85(4 \mathrm{H}, \mathrm{m}), 3.46(1 \mathrm{H}, \mathrm{dd}, J=4.4$, 2.8 Hz), 2.28-2.03 (3H, m), 1.98-1.85 (2H, m), 1.59-1.47 (2H, m), 1.25 (3H, s), 1.13-1.09 (1H, m), 1.06 (3H, s), $1.02(3 \mathrm{H}, \mathrm{s}), 0.86(9 \mathrm{H}, \mathrm{s}), 0.00(3 \mathrm{H}, \mathrm{s}),-0.01(3 \mathrm{H}, \mathrm{s}) ;{ }^{13} \mathrm{C}$ NMR (100 MHz, $\left.\mathrm{CDCl}_{3}\right) \delta$ 147.4, 118.9, 113.4, 77.6, 65.6, 65.2, 42.7, 41.0, 30.5, 28.5, 27.0, 26.8, 26.2, 25.8, 24.4, 23.0, 18.5, -4.1, -4.5; IR (neat) 2952, 1472, 1252, $1089 \mathrm{~cm}^{-1}$; HRMS (EI) calcd for $\mathrm{C}_{21} \mathrm{H}_{38} \mathrm{O}_{3} \mathrm{Si}\left(\mathrm{M}^{+}\right)$366.2590, found 366.2636; $[\alpha]_{\mathrm{D}}^{20}+70.4\left(c 1.15, \mathrm{CHCl}_{3}\right)$.

(6S,8aR)-6-(tert-Butyldimethylsilyloxy)-6,7,8,8a-tetrahydro-5,5,8a-trimethyl-1,3(2H,5H)-naphthalenedione 1-ethylene ketal (18). At $0{ }^{\circ} \mathrm{C}$, a solution of $\mathrm{CrO}_{3}(62.4 \mathrm{~g}, 624 \mathrm{mmol})$ dissolved in $\mathrm{CH}_{2} \mathrm{Cl}_{2}(500$ $\mathrm{mL}$ ) was added 3,5-dimethylpyrazole (60 g, $624 \mathrm{mmol})$, stirred for $30 \mathrm{~min}$. Then the solution of 13 (10.4 g, $28.4 \mathrm{mmol})$ in $\mathrm{CH}_{2} \mathrm{Cl}_{2}(100 \mathrm{~mL})$ was cannulated to the above prepared black mixture. After $5 \mathrm{~h}$ under stirring at room temperature, $3 \mathrm{M} \mathrm{NaOH}(800 \mathrm{~mL})$ was added. The resulting mixture was extracted with $\mathrm{CH}_{2} \mathrm{Cl}_{2}$ (200 mL x 3). The extracts were washed with saturated aqueous solution of $\mathrm{NaHCO}_{3}$, water, dried and evaporated under reduced pressure. The residue was purified by flash column chromatography on silica gel (hexane/EtOAc $=10: 1)$ to give $18(8.8 \mathrm{~g}, 82 \%)$ as a white solid. 
Mp 113-114 ${ }^{\circ} \mathrm{C} ;{ }^{1} \mathrm{H}$ NMR (400 MHz, $\mathrm{CDCl}_{3}$ ) $\delta 5.97$ (1H, s), 3.91-3.84 (4H, m), 3.54 (1H, dd, $J=4.4 \mathrm{~Hz}$, $2.8 \mathrm{~Hz}), 2.78(1 \mathrm{H}, \mathrm{d}, J=17.2 \mathrm{~Hz}), 2.51(1 \mathrm{H}, \mathrm{d}, J=17.2 \mathrm{~Hz}), 2.38-2.30(1 \mathrm{H}, \mathrm{m}), 2.07-1.98(1 \mathrm{H}, \mathrm{m})$, 1.63-1.56 (1H, m), 1.41 (3H, s), 1.26-1.21 (1H, m), 1.43 (3H, s), 1.13 (3H, s), 0.84 (9H, s), 0.01 (3H, s), 0.00 (3H, s); ${ }^{13} \mathrm{C}$ NMR (100 MHz, $\left.\mathrm{CDCl}_{3}\right) \delta$ 197.8, 176.0, 124.6, 113.0, 76.1, 65.6, 65.2, 44.5, 44.2, 42.5, 29.3, 27.6, 25.7, 25.5, 24.8, 22.4, 18.0, -4.5, -4.9; IR (KBr) 2956, 1662, $1091 \mathrm{~cm}^{-1}$; HRMS (EI) calcd for $\mathrm{C}_{21} \mathrm{H}_{36} \mathrm{O}_{4} \mathrm{Si}\left(\mathrm{M}^{+}\right)$380.2383, found 380.2387; $[\alpha]_{\mathrm{D}}{ }^{20}+16.9$ (c 1.60, $\left.\mathrm{CHCl}_{3}\right)$.

(4aR,6S,8aR)-6-(tert-Butyldimethylsilyloxy)-4a,5,6,7,8,8a-hexahydro-5,5,8a-trimethyl-1,3(2H,4H)naphthalenedione 1-ethylene ketal (19) and (4aS,6S,8aR)-6-(tert-Butyldimethylsilyloxy)4a,5,6,7,8,8a-hexahydro-5,5,8a-trimethyl-1,3(2H,4H)-naphthalenedione 1-ethylene ketal (19'). Sodium (460 mg, $20 \mathrm{mmol})$ was added to liquid ammonia (100 mL) while cooling in a liquid nitrogenacetone bath. After $0.5 \mathrm{~h}$, a solution of 18 (760 mg, $2.0 \mathrm{mmol})$ and $t$-butanol (210 $\mu \mathrm{L}, 2.2 \mathrm{mmol})$ in dry $\mathrm{Et}_{2} \mathrm{O}(30 \mathrm{~mL})$ was introduced. Increasing the temperature to $-35{ }^{\circ} \mathrm{C}$, and maintained for $0.5 \mathrm{~h}$ at that temperature before being quenched with solid $\mathrm{NH}_{4} \mathrm{Cl}$. After evaporation of the ammonia gas, the resultant slurry was treated with water $(50 \mathrm{~mL})$ and EtOAc $(50 \mathrm{~mL})$, and the precipitate was filtered through Celite and washed thoroughly. The filtrate was extracted with EtOAc $(50 \mathrm{~mL}$ x 3). The extracts were washed with water and brine, dried over $\mathrm{Na}_{2} \mathrm{SO}_{4}$, filtered, and evaporated under reduced pressure. The residue was purified by flash column chromatography on silica gel (hexane/EtOAc $=20: 1)$ afforded the 19 (460 mg, 60\%, colorless oil) and 19’(100 mg, 13\%, colorless oil).

19: ${ }^{1} \mathrm{H}$ NMR (400 MHz, $\left.\mathrm{CDCl}_{3}\right) \delta 3.96-3.83$ (4H, m), 3.39 (1H, brs), 2.67 (1H, d, $\left.J=15.2 \mathrm{~Hz}\right), 2.43-$ 2.19 (4H, m), 2.06-1.99 (1H, m), 1.88-1.80 (1H, m), 1.52-1.46 (1H, m), 1.18-1.12 (4H, m), 0.87 (9H, s), 0.84 (3H, s), 0.82 (3H, s), 0.02 (3H, s), -0.01 (3H, s); ${ }^{13} \mathrm{C}$ NMR (100 MHz, $\left.\mathrm{CDCl}_{3}\right) \delta$ 208.8, 113.6, 76.2, 65.5, 48.5, 42.4, 38.8, 38.3, 38.3, 28.8, 25.8, 25.3, 23.3, 21.2, 18.1, 16.5, -4.5, -4.8; IR (neat) 2957, 1712, 1257, 1156, $1075 \mathrm{~cm}^{-1}$; HRMS (EI) calcd for $\mathrm{C}_{17} \mathrm{H}_{29} \mathrm{O}_{4} \mathrm{Si}\left(\mathrm{M}^{+}-57\right)$ 325.1835, found 325.1793; $[\alpha]_{\mathrm{D}}^{20}$ $+45.2\left(\right.$ ( $\left.1.65, \mathrm{CHCl}_{3}\right)$.

19': ${ }^{1} \mathrm{H}$ NMR (400 MHz, CDCl 3 ) $\delta$ 4.01-3.91 (4H, m), 3.42 (1H, dd, J = 5.6, 3.2 Hz), 3.10-3.03 (1H, m), 2.76-2.71 (1H, m), 2.50-2.44 (1H, m), 2.11-2.04 (1H, m), 1.90-1.82 (1H, m), 1.73-1.64 (2H, m), 1.36$1.30(1 \mathrm{H}, \mathrm{m}), 1.18$ (3H, s), 1.05 (3H, s), 0.93 (3H, s), 0.87 (9H, s), $0.04(3 \mathrm{H}, \mathrm{s}), 0.03(3 \mathrm{H}, \mathrm{s}) ;{ }^{13} \mathrm{C}$ NMR $\left(100 \mathrm{MHz}, \mathrm{CDCl}_{3}\right) \delta$ 208.9, 114.3, 76.5, 65.3, 64.7, 48.3, 46.5, 42.1, 42.1, 38.8, 30.4, 27.2, 25.9, 24.8, 23.6, 18.0, -4.4, -5.0; IR (neat) 2954, 1717, 1252, $1074 \mathrm{~cm}^{-1}$; HRMS (EI) calcd for $\mathrm{C}_{21} \mathrm{H}_{38} \mathrm{O}_{4} \mathrm{Si}\left(\mathrm{M}^{+}\right)$ 382.2539, found 382.2528; $[\alpha]_{\mathrm{D}}{ }^{20}+119.2\left(c \mathrm{c} 0.58, \mathrm{CHCl}_{3}\right)$.

(4aR,6S,8aR)-6-(tert-Butyldimethylsilyloxy)-4a,5,6,7,8,8a-hexahydro-5,5,8a-trimethyl-1,3(2H,4H)naphthalenedione (12). A solution of 19 (5.02 g, $13.1 \mathrm{mmol})$ in THF (600 mL) was treated with $1 \mathrm{M} \mathrm{HCl}$ (65.6 mL), heated to $60{ }^{\circ} \mathrm{C}$ for $15 \mathrm{~h}$, and diluted with water. The aqueous phase was extracted with EtOAc (200 mL x 3) and the combined organic phases were washed with brine, dried, and evaporated. 
Chromatography of the residue on silica gel (hexane/EtOAc = 3:1) afforded 12 (4.3 g, 97\%) as a white solid.

Mp 205-207 ${ }^{\circ} \mathrm{C} ;{ }^{1} \mathrm{H}$ NMR (400 MHz, $\mathrm{CDCl}_{3}$ ) $\delta$ 3.48-3.32 (3H, m), 2.54 (1H, d, $\left.J=9.6 \mathrm{~Hz}\right), 2.07-1.98$ (2H, m), 1.91-1.83 (1H, m), 1.61-1.51 (2H, m), 1.16 (3H, s), 0.93 (3H, s), 0.90 (3H, s), 0.85 (9H, s), 0.04 (3H, s), 0.01 (3H, s); ${ }^{13} \mathrm{C}$ NMR (100 MHz, $\left.\mathrm{CDCl}_{3}\right) \delta$ 208.3, 205.2, 75.7, 54.5, 47.1, 38.9, 38.2, 37.6, 28.6, 26.1, 25.9, 24.9, 21.8, 18.1, 17.4, -4.4, -4.9; IR (KBr) 2951, 1610, 1530, 1473, 1313, $1225 \mathrm{~cm}^{-1}$; HRMS (EI) calcd for $\mathrm{C}_{19} \mathrm{H}_{34} \mathrm{O}_{3} \mathrm{Si}\left(\mathrm{M}^{+}\right)$338.2277, found 338.2274; $[\alpha]_{\mathrm{D}}{ }^{20}+54.3\left(\right.$ c 0.90, $\left.\mathrm{CHCl}_{3}\right)$.

\section{(4aR,6S,8aR)-3-(iso-Butoxy)-6-(tert-butyldimethylsilyloxy)-4a,5,6,7,8,8a-hexahydro-5,5,8a-}

trimethyl-1(4H)-naphthalenone (20). A $500 \mathrm{~mL}$ round flask equipped with Dean-Stark apparatus was charged with 12 (3.23 g, $9.56 \mathrm{mmol})$ and cyclohexane $(134 \mathrm{~mL})$, then $i$-butanol $(20 \mathrm{~mL})$ and $p$-TsOH ( $0.91 \mathrm{~g}, 4.78 \mathrm{mmol}$ ) were added. The resulting mixture was refluxed for $1.5 \mathrm{~h}$, and then quenched with triethylamine. The reaction mixture was extracted with EtOAc $(100 \mathrm{~mL}$ x 3). The combined organic layers were washed with brine, dried over $\mathrm{Na}_{2} \mathrm{SO}_{4}$ and concentrated in vacuo. The residue was purified by flash column chromatography on silica gel (hexane/EtOAc $=6: 1)$ to give 20 (3.13 g, 83\%) as a colorless oil.

${ }^{1} \mathrm{H}$ NMR (400 MHz, $\left.\mathrm{CDCl}_{3}\right) \delta 5.15(1 \mathrm{H}, \mathrm{d}, J=1.6 \mathrm{~Hz}), 3.59-3.51(2 \mathrm{H}, \mathrm{m}), 3.38(1 \mathrm{H}, \mathrm{d}, J=2.4 \mathrm{~Hz})$, 2.42-2.34 (1H, m), 2.22 (1H, dd, $J=17.2,4.4 \mathrm{~Hz}$ ), 2.10 (1H, dd, $J=13.2,4.4 \mathrm{~Hz}), 2.03-1.96$ (1H, m), 1.85-1.82 (2H, m), 1.59-1.53 (2H, m), 1.04 (3H, s), 0.97-0.94 (9H, m), 0.89 (3H, s), 0.84 (9H, s), 0.02 (3H, s), 0.01 (3H, s); ${ }^{13} \mathrm{C}$ NMR (100 MHz, $\left.\mathrm{CDCl}_{3}\right) \delta$ 206.0, 176.4, 100.2, 76.0, 74.6, 44.0, 41.4, 38.5, 28.4, 27.8, 27.0, 26.1, 25.9, 25.3, 22.2, 19.1, 19.1, 18.1, 18.1, 17.9, -4.4, -5.0; IR (neat) 2956, 1659, 1616, 1206, $1075 \mathrm{~cm}^{-1}$; HRMS (EI) calcd for $\mathrm{C}_{23} \mathrm{H}_{42} \mathrm{O}_{3} \mathrm{Si}\left(\mathrm{M}^{+}\right)$394.2903, found 394.2942; $[\alpha]_{\mathrm{D}}{ }^{20}+77.5$ (c 2.80, $\left.\mathrm{CHCl}_{3}\right)$.

(4aR,6S,8aR)-6-(tert-Butyldimethylsilyloxy)-4a,5,6,7,8,8a-hexahydro-5,5,8a-trimethyl-1-(1-propen-1 -yl)-3(4H)-naphthalenone (21). A solution of 20 (346 mg, $0.88 \mathrm{mmol}$ ) in dry THF (5 mL) was treated at $0{ }^{\circ} \mathrm{C}$ with (E)-prop-1-en-1-ylmagnesium bromide $(3.5 \mathrm{~mL}, 3.5 \mathrm{mmol}$ ) which was freshly prepared from (E)-1-bromoprop-1-ene. After $2 \mathrm{~h}$ under stirring at room temperature, $10 \% \mathrm{HCl}$ was added. The resulting mixture was extracted with EtOAc $(20 \mathrm{~mL} \mathrm{x} \mathrm{3)}$. The combined organic extracts were washed with water and brine, dried over $\mathrm{Na}_{2} \mathrm{SO}_{4}$ and evaporated under reduced pressure. The residue was purified by flash column chromatography on silica gel (hexane/EtOAc = 10:1) to give 21 (235 mg, 74\%) as a colorless oil.

${ }^{1} \mathrm{H}$ NMR (400 MHz, $\mathrm{CDCl}_{3}$ ) $\delta$ 6.17-6.14 (2H, m), 5.89 (1H, s), 3.40 (1H, s), 2.33-2.20 (3H, m), 2.021.88 (1H, m), 1.82-1.77 (4H, m), 1.58-1.51 (2H, m), 1.10 (3H, s), 0.90 (3H, m), 0.85 (9H, s), 0.85 (3H, s), 0.03 (3H, s), 0.01 (3H, s); ${ }^{13} \mathrm{C}$ NMR (100 MHz, $\left.\mathrm{CDCl}_{3}\right) \delta$ 201.0, 170.3, 132.9, 126.9, 121.1, 75.4, 43.4, 38.7, 38.1, 34.7, 29.0, 28.5, 25.9, 25.7, 21.5, 18.9, 18.8, 18.1, -4.4, -5.0; IR (neat) 2955, 1663, 1256, 
$1076 \mathrm{~cm}^{-1}$; HRMS (EI) calcd for $\mathrm{C}_{22} \mathrm{H}_{38} \mathrm{O}_{2} \mathrm{Si}\left(\mathrm{M}^{+}\right)$362.2641, found 362.2617; $[\alpha]_{\mathrm{D}}{ }^{20}-29.5$ (c 1.15, $\mathrm{CHCl}_{3}$ ).

(3S,4aR,6S,8aR)-6-(tert-Butyldimethylsilyloxy)-3,4,4a,5,6,7,8,8a-octahydro-3-hydroxy-5,5,8a-trimethyl-1-(1-propen-1-yl)-naphthalene (11) and (3R,4aR,6S,8aR)-6-(tert-Butyldimethylsilyloxy)3,4,4a,5,6,7,8,8a-octahydro-3-hydroxy-5,5,8a-trimehyl-1-(1-propen-1-yl)-naphthalene (11'). To a stirred solution of 21 (200 mg, $0.55 \mathrm{mmol})$ in $\mathrm{CH}_{2} \mathrm{Cl}_{2}(40 \mathrm{~mL})$ was added DIBAL (1.66 mL, $\left.1.66 \mathrm{mmol}\right)$ at $0{ }^{\circ} \mathrm{C}$. After stirring for $15 \mathrm{~min}$ at the same temperature, the reaction mixture was treated with saturated aqueous $\mathrm{NH}_{4} \mathrm{Cl}$ solution $(2 \mathrm{~mL})$. The reaction mixture was extracted with EtOAc $(20 \mathrm{~mL} \times 3)$. The combined organic layers were washed with brine, dried over $\mathrm{Na}_{2} \mathrm{SO}_{4}$ and concentrated in vacuo. The residue was purified by flash column chromatography on silica gel (hexane/EtOAc $=20: 1$ ) to give 11 (18 mg, 9\%, colorless oil) and 11'(159 mg, 79\%, colorless oil).

11: ${ }^{1} \mathrm{H}$ NMR (400 MHz, CDCl 3 ) $\delta 5.99(1 \mathrm{H}, \mathrm{d}, J=15.2 \mathrm{~Hz}), 5.86-5.77(1 \mathrm{H}, \mathrm{m}), 5.59(1 \mathrm{H}, \mathrm{d}, J=4.8 \mathrm{~Hz})$, 4.16 (1H, s), 3.41 (1H, dd, $J=2.8,2.8 \mathrm{~Hz}), 1.94-1.82$ (2H, m), 1.75-1.63 (6H, m), 1.54-1.40 (3H, m), 0.95 (3H, s), 0.90 (3H, m), 0.89 (9H, s), 0.85 (3H, s), 0.04 (3H, s), 0.04 (3H, s); ${ }^{13} \mathrm{C}$ NMR (100 MHz, $\left.\mathrm{CDCl}_{3}\right) \delta 152.1,128.6,127.1,120.6,76.2,65.2,38.7,37.9,37.9,29.8,29.1,27.9,26.1,26.0,22.0,18.9$, 18.4, 18.2, -4.3, -4.8; IR (neat) 3427, 2956, 1256, 1081, $1020 \mathrm{~cm}^{-1}$; HRMS (EI) calcd for $\mathrm{C}_{22} \mathrm{H}_{40} \mathrm{O}_{2} \mathrm{Si}$ $\left(\mathrm{M}^{+}\right)$364.2798, found 364.2796; $[\alpha]_{\mathrm{D}}{ }^{20}+20.4\left(c\right.$ 0.81, $\left.\mathrm{CHCl}_{3}\right)$.

11': ${ }^{1} \mathrm{H}$ NMR (400 MHz, $\left.\mathrm{CDCl}_{3}\right) \delta 5.93(1 \mathrm{H}, \mathrm{d}, J=16.0 \mathrm{~Hz}), 5.85-5.76(1 \mathrm{H}, \mathrm{m}), 5.46(1 \mathrm{H}, \mathrm{s}), 4.27(1 \mathrm{H}, \mathrm{t}$, $J=8.4 \mathrm{~Hz}$ ), 3.37 (1H, dd, $J=2.8,2.8 \mathrm{~Hz}), 1.96-1.87$ (2H, m), 1.73-1.67 (4H, m), 1.63-1.55 (2H, m), 1.51-1.29 (3H, m), 1.06 (3H, s), $0.88(9 \mathrm{H}, \mathrm{s}), 0.86(3 \mathrm{H}, \mathrm{s}), 0.85(3 \mathrm{H}, \mathrm{s}), 0.03(3 \mathrm{H}, \mathrm{s}), 0.02(3 \mathrm{H}, \mathrm{s}) ;{ }^{13} \mathrm{C}$ NMR (100 MHz, $\left.\mathrm{CDCl}_{3}\right) \delta 150.0,128.5,126.4,122.8,75.8,69.8,43.1,37.9,37.7,29.9,29.0,28.8,26.0$, 25.9, 22.0, 20.6, 18.4, 18.2, -4.4, -4.9; IR (neat) 3298, 2957, 1257, 1078, $1015 \mathrm{~cm}^{-1}$; HRMS (EI) calcd for $\mathrm{C}_{22} \mathrm{H}_{40} \mathrm{O}_{2} \mathrm{Si}\left(\mathrm{M}^{+}\right)$364.2798, found 364.2795; $[\alpha]_{\mathrm{D}}{ }^{20}+11.6$ (c 0.58, $\left.\mathrm{CHCl}_{3}\right)$.

Pentacyclic ketolactone 8 and triene 22. To a solution of the alcohol 11' (18.2 mg, $0.05 \mathrm{mmol})$ in THF $(1 \mathrm{~mL})$ were added $\mathrm{PPh}_{3}(39.3 \mathrm{mg}, 0.15 \mathrm{mmol})$ and diethyl azodicarboxylate $(28 \mathrm{mg}, 0.16 \mathrm{mmol})$ at $0{ }^{\circ} \mathrm{C}$. Then carboxylic acid $\mathbf{1 0}^{3}$ (8.4 mg, $0.06 \mathrm{mmol}$ ) was added to the above mixture and stirred for $1 \mathrm{~h}$ at room temperature. The resulting mixture was extracted with $\mathrm{CH}_{2} \mathrm{Cl}_{2}(10 \mathrm{~mL}$ x 3). The extracts were washed with aqueous saturated solution of $\mathrm{NaHCO}_{3}$, water, dried and evaporated under reduced pressure to give a brown oil, which was dissolved in toluene $(0.5 \mathrm{~mL})$ in a sealed tube and heated to reflux for $15 \mathrm{~h}$. The resulting solution was concentrated in vacuo, the residue was purified by flash column chromatography on silica gel (hexane/EtOAc = 3:1) to give 8 (2.4 mg, 10\%, white solid) and 22 (8.7 mg, 50\%, colorless oil).

8: ${ }^{1} \mathrm{H}$ NMR (400 MHz, $\left.\mathrm{CDCl}_{3}\right) \delta 5.16$ (1H, brs), 5.07-5.02 (1H, m), $3.44(1 \mathrm{H}, \mathrm{m}), 3.20-3.19(1 \mathrm{H}, \mathrm{m})$, 2.47-2.20 (1H, m), 2.16-2.03 (3H, m), 2.00-1.88 (3H, m), 1.79-1.66 (2H, m), 1.39-1.34 (1H, m), 1.26- 
1.24 (1H, m), 1.21 (3H, s), 1.01 (3H, d, J = $7.6 \mathrm{~Hz}$ ), 1.00 (3H, s), 0.89 (3H, s), 0.82 (9H, s), 0.81 (3H, s), 0.03 (3H, s), $0.01(3 \mathrm{H}, \mathrm{s})$.

22: ${ }^{1} \mathrm{H}$ NMR (400 MHz, $\left.\mathrm{CDCl}_{3}\right) \delta$ 6.83-6.74 (1H, m), $6.53(1 \mathrm{H}, \mathrm{d}, J=9.2 \mathrm{~Hz}), 5.88(2 \mathrm{H}, \mathrm{d}, J=10.0 \mathrm{~Hz})$, 5.18 (1H, dd, $J=16.8,2.0 \mathrm{~Hz}$ ), 5.06 (1H, dd, $J=10.0,2.0 \mathrm{~Hz}), 3.40$ (1H, d, $J=4.0 \mathrm{~Hz}), 2.15-2.03(2 \mathrm{H}$, m), 1.98-1.89 (2H, m), 1.81-1.77 (2H, m), 1.59-1.52 (2H, m), 1.00 (3H, s), 0.92 (3H, s), 0.88 (9H, s), 0.87 (3H, s), 0.05 (3H, s), 0.02 (3H, s); ${ }^{13} \mathrm{C}$ NMR (100 MHz, $\mathrm{CDCl}_{3}$ ) $\delta 148.9,133.0,129.7,122.7,120.4$, 115.8, 76.4, 42.1, 38.3, 37.4, 29.4, 28.9, 26.0, 25.9, 23.9, 22.4, 21.2, 18.2, -4.3, -4.9; IR (neat) 2956, 1472, 1256, $1078 \mathrm{~cm}^{-1}$; HRMS (EI) calcd for $\mathrm{C}_{22} \mathrm{H}_{38} \mathrm{OSi}\left(\mathrm{M}^{+}\right)$346.2692, found 346.2689; $[\alpha]_{\mathrm{D}}{ }^{20}+817.6$ (c $\left.0.42, \mathrm{CHCl}_{3}\right)$.

\section{ACKNOWLEDGEMENTS}

We thank to Mr. Uchida for his preliminary work on the Diels-Alder strategy. Dr. Shiro is also acknowledged for the assistance of X-ray crystallographic analysis.

\section{REFERENCES}

1. a) K. Shiomi, R. Uchida, J. Inokoshi, H. Tanaka, Y. Iwai, and S. Ōmura, Tetrahedron Lett., 1996, 37, 1265; b) S. Ōmura, J. Inokoshi, R. Uchida, K. Shiomi, R. Masuma, T. Kawakubo, H. Tanaka, Y. Iwai, S. Kosemura, and S. Yamamura, J. Antibiot., 1996, 49, 414; c) R. Uchida, K. Shiomi, J. Inokoshi, T. Sunazuka, H. Tanaka, Y. Iwai, H. Takayanagi, and S. Ōmura, J. Antibiot., 1996, 49, 418; d) R. Uchida, K. Shiomi, J. Inokoshi, H. Tanaka, Y. Iwai, and S. Ōmura, J. Antibiot., 1996, 49, 1278.

2. a) D. Schinzer and K. Ringe, Tetrahedron, 1996, 52, 7475; b) M. Tori, C. Makino, K. Hisazumi, M. Sono, and K. Nakashima, Tetrahedron: Asymmetry, 2001, 12, 301; c) A. Srikrishna and D. Vijaykumar, J. Chem. Soc., Perkin Trans. 1, 2000, 2583; d) A. Srikrishna and K. Anebouselvy, Tetrahedron Lett., 2003, 44, 1031; e) A. Srikrishna and C. Dinesh, Tetrahedron: Asymmetry, 2005, 16, 2203; f) C.-K. Sha, H.-W. Liao, P.-C. Cheng, and S.-C. Yen, J. Org. Chem., 2003, 68, 8704; g) P. A. Clarke, R. J. G. Black, and A. J. Blake, Tetrahedron Lett., 2006, 47, 1453; h) K. Harada, Y. Tonoi, H. Kato, and Y. Fukuyama, Tetrahedron Lett., 2002, 43, 3829; i) M. Toyota, A. Ilangovan, R. Okamoto, T. Masaki, M. Arakawa, and M. Ihara, Org. Lett., 2002, 4, 4293; j) J. J. Kennedy-Smith, S. T. Staben, and F. D. Toste, J. Am. Chem. Soc., 2004, 126, 4526; k) S. T. Staben, J. J. Kennedy-Smith, D. Huang, B. K. Corkey, R. L. LaLonde, and F. D. Toste, Angew. Chem. Int. Ed., 2006, 45, 5991; l) M. Mori, T. Takaki, M. Makabe, and Y. Sato, Tetrahedron Lett., 2003, 44, 3797; m) M. E. Jung, D. Ho, and H. V. Chu, Org. Lett., 2005, 7, 1649; n) J. Shiina and S. Nishiyama, Tetrahedron Lett., 2005, 46, 7683; o) J. Shiina, M. Oikawa, K. Nakamura, R. Obata, and S. Nishiyama, Eur. J. Org. Chem., 
2007, 5190; p) R. Okamoto, K. Takeda, H. Tokuyama, M. Ihara, and M. Toyota, J. Org. Chem., 2013, 78, 93.

3. S. Yin, K. Takai, D. Minato, K. Sugimoto, H. Ohtsu, K. Tsuge, and Y. Matsuya, Heterocycles, prepress (DOI: 10:3987/COM-15-S(T)34).

4. a) P. Buchschacher, A. Fürst, and J. Gutzwiller, Org. Synth. Coll. Vol. 7, 1990, 368; b) N. Harada, T. Sugioka, H. Uda, and T. Kuriki, Synthesis, 1990, 53.

5. $\quad$ W. G. Dauben, M. Lorber, and D. S. Fullerton, J. Org. Chem., 1969, 34, 3587.

6. a) O. Mitsunobu, M. Yamada, and T. Mukaiyama, Bull. Chem. Soc. Jpn., 1967, 40, 935; b) O. Mitsunobu and M. Yamada, Bull. Chem. Soc. Jpn., 1967, 40, 2380; c) O. Mitsunobu, Synthesis, 1981, 1.

7. Stereoelectronic Cieplak effect from adjacent axial two $\mathrm{C}-\mathrm{H}$ bonds could not be excluded. 